\title{
COMPARISON OF DROTAVERINE HYDROCHLORIDE AND VALETHAMATE BROMIDE ON CERVICAL DILATATION
}

\author{
S. Mallika Selvaraj ${ }^{1}$, Sumathi Natarajan ${ }^{2}$ \\ ${ }^{1}$ Assistant Professor, Department of Obstetrics \& Gynaecology, Madurai Medical College. \\ 2 Professor, Department of Obstetrics \& Gynaecology, Madurai Medical College.
}

\section{ABSTRACT}

AIM

To compare the two drugs drotaverine hydrochloride and valethamate bromide and their effects on cervical dilatation and labour duration.

\section{METHODOLOGY}

It is a prospective study undertaken at Government Rajaji Hospital on 150 randomly selected primigravidae patients.

\section{RESULTS}

The duration of active phase of first stage of labour was significantly reduced (p value 0.003), rate of cervical dilatation was higher ( $\mathrm{p}$ value 0.0001 ) with drotaverine hydrochloride.

\section{CONCLUSION}

Drotaverine hydrochloride is a safe, potent and effective drug to be used in the active phase of labour.

\section{KEYWORDS}

Cervical Dilatation, Drotaverine Hydrochloride, Pain Relief.

HOW TO CITE THIS ARTICLE: Selvaraj SM, Natarajan S. Comparison of drotaverine hydrochloride and valethamate bromide on cervical dilatation. J. Evolution Med. Dent. Sci. 2016;5(52):3391-3394, DOI: 10.14260/jemds/2016/783

\section{INTRODUCTION}

Obstetrics is a fine art built on facts gathered by scientific research. The last few hours of human pregnancy are characterized by uterine contractions that effect the dilatation of cervix and force the foetus through birth canal. The myometrial contractions of labour are painful, which is why the term 'labour pains' are used to describe this process. Painless and short labour is desired by every mother and a constant aim for obstetricians. Cervical dilatation is one of the most important factors, which determines the duration of labour and is the resultant of all the driving forces of uterine contraction acting against passive tissue resistance. In the process of labour, polarity of the uterus is maintained by active contractions of the upper uterine segment. The driving forces of the uterine contractions act upon the cervix, which play the role of an innocent obstruction due to passive tissue resistance. Failure of the cervix to dilate in labour can cause prolonged labour. Overacting of the circular muscle fibres of cervix results in cervical spasm, which may be increased in presence of inflammation, injury or fibrosis of cervix or due to "fear tension pain syndrome." Various drugs like antispasmodics, tranquilizers, prostaglandins and psychotherapeutic methods have been tried, but majority of these were found to have ill effects on the mother and the foetus. One such drug without complication is drotaverine hydrochloride. "It is common axiom not to allow the sun to set

Financial or Other, Competing Interest: None.

Submission 12-05-2016, Peer Review 07-06-2016,

Acceptance 13-06-2016, Published 29-06-2016.

Corresponding Author:

Dr. Sumathi Natarajan

Suba Clinic, \#2, Tagore Nagar,

Thiruppalai,

Madurai-625014.

E-mail: sumathibaskaran88@gmail.com

DOI: $10.14260 /$ jemds $/ 2016 / 783$ twice on a woman in labour." The most important consideration in pregnancy is that there are in fact two individuals receiving treatment, "the mother and the baby."

\section{AIM OF THE STUDY}

The aims of the study are,

1. To study the effect of the drug drotaverine hydrochloride on cervical dilatation and its effect, its side effects on the mother and the foetus.

2. Critical evaluation of the efficacy of drotaverine hydrochloride with valethamate bromide.

3. To study the degree of pain relief in labour with drotaverine hydrochloride.

\section{MATERIALS AND METHODS}

The prospective study was undertaken at Government Rajaji Hospital attached to Madurai Medical College in Obstetrics and Gynaecological Department, 150 consecutive primigravidae were selected at random manner from the patients admitted in the clean labour ward that includes both booked and unbooked cases.

\section{The Inclusion Criteria for the Patients}

Following criteria were utilized in selecting patients for this study - Full term pregnancy with established labour pains in Primigravid, Vertex presentation, Cervix more than $3 \mathrm{~cm}$ dilated and $75 \%$ effaced. No cephalopelvic disproportion. No clinical evidence of foetal distress with no high risk factors. Labour was accelerated with syntocinon if necessary, induced labour for postdatism. The primigravida who fulfilled the above said criteria were classified into three groups. Group I, II and III.

\section{THE METHOD}

In the selected patients, labour was monitored by partogram with meticulous recording of all events taking place during 
labour. As the women enter into active phase of labour as assessed from partogram with $75 \%$ effacement and $3 \mathrm{~cm}$ dilatation drugs to augment cervical dilatation were given, dividing into 3 groups each consisting of 50 patients. Exclusion criteria included patients with medical disorder complicating pregnancy like epilepsy, psychotic illness, patients with previous caesarean section, patients with any other obstetric complications like twin pregnancy, hydramnios, preterm labour and severe PIH, CPD (borderline CPD), those on antiallergic drug and anti-hypertensives, known glaucoma. In Group 1, patients were given injection drotaverine hydrochloride $40 \mathrm{mg} \mathrm{IM}$ and repeated every 2 hours for a maximum of 3 injections.

In Group II, patients were given injection of valethamate bromide $8 \mathrm{mg}$ intravenous every hour for five doses. In Group III, patients were not given any drugs and acted as controls.

\section{OBSERVATIONS AND RESULTS}

This study was conducted on 150 primiparturients and they were randomly allocated into 3 groups as told above.

\begin{tabular}{|c|c|c|c|c|c|c|c|c|}
\hline $\begin{array}{c}\text { Age Group } \\
\text { Years }\end{array}$ & \multicolumn{2}{|c|}{ Group I } & \multicolumn{2}{|c|}{ Group II } & \multicolumn{2}{|c|}{ Group III } & \multicolumn{2}{|c|}{ Percentage } \\
\hline & No. & $\%$ & No. & $\%$ & No. & $\%$ & No. & \% \\
\hline $15-20$ yrs. & 15 & 30 & 18 & 36 & 15 & 30 & 48 & 32 \\
\hline $21-25$ yrs. & 27 & 54 & 23 & 46 & 28 & 56 & 78 & 52 \\
\hline $26-30$ yrs. & 8 & 16 & 9 & 18 & 7 & 14 & 24 & 16 \\
\hline Mean & 22.3 & & 22.2 & & 22.2 & & & \\
\hline SD & \pm 2.6 & & \pm 3.2 & & \pm 2.7 & & & \\
\hline
\end{tabular}

There was no significant difference among the groups regarding age distribution; $70-80 \%$ of the patients belong to the child bearing age, i.e. 21-25 years. The mean age in years were 22.3, 22.2 and 22.2 in group I, group II and group III respectively.

\section{RESULTS}

\section{Average Data}

\begin{tabular}{|c|c|c|c|c|c|c|}
\hline Group & $\begin{array}{c}\text { Duration } \\
\text { of Active } \\
\text { Phase }\end{array}$ & $\begin{array}{c}\text { Rate of } \\
\text { Cervical } \\
\text { Dilatation }\end{array}$ & $\begin{array}{c}\text { Second } \\
\text { Stage of } \\
\text { Labour }\end{array}$ & $\begin{array}{c}\text { Injection } \\
\text { Delivery } \\
\text { Interval }\end{array}$ & $\begin{array}{c}\text { Apgar } \\
\text { Score } \\
\text { 1 min }\end{array}$ & $\begin{array}{c}\text { Apgar } \\
\text { Score } \\
\mathbf{5} \text { mins }\end{array}$ \\
\hline $\begin{array}{c}\text { Group } \\
\text { I }\end{array}$ & $\begin{array}{c}3 \mathrm{hrs} . \\
18 \mathrm{~min}\end{array}$ & $2.2 \mathrm{~cm} / \mathrm{hr}$. & $\begin{array}{c}21.2 \\
\mathrm{~min}\end{array}$ & $\begin{array}{c}3 \mathrm{hrs} . \\
40 \mathrm{~min}\end{array}$ & 6.8 & 8.8 \\
\hline $\begin{array}{c}\text { Group } \\
\text { II }\end{array}$ & $\begin{array}{c}4 \mathrm{hrs} . \\
12 \mathrm{~min}\end{array}$ & $1.68 \mathrm{~cm} / \mathrm{hr}$. & $\begin{array}{c}22.74 \\
\mathrm{~min}\end{array}$ & $\begin{array}{c}4 \mathrm{hrs} . \\
35 \mathrm{~min}\end{array}$ & 6.64 & 8.58 \\
\hline $\begin{array}{c}\text { Group } \\
\text { II }\end{array}$ & $\begin{array}{c}6 \mathrm{hrs} . \\
23 \mathrm{~min}\end{array}$ & $1.11 \mathrm{~cm} / \mathrm{hr}$. & $\begin{array}{c}30.94 \\
\mathrm{~min}\end{array}$ & $\begin{array}{c}6 \mathrm{hrs} . \\
54 \mathrm{~min}\end{array}$ & 6.22 & 8.08 \\
\hline
\end{tabular}

\begin{tabular}{|c|c|c|c|c|c|c|}
\hline Group & $\begin{array}{c}\text { Duration } \\
\text { of Active } \\
\text { Phase } \\
\text { (min) }\end{array}$ & $\begin{array}{c}\text { Rate of } \\
\text { Cervical } \\
\text { Dilatation } \\
\text { (cm/hr.) }\end{array}$ & $\begin{array}{c}\text { Second } \\
\text { Stage of } \\
\text { Labour } \\
\text { (min) }\end{array}$ & $\begin{array}{c}\text { Injection } \\
\text { Delivery } \\
\text { Interval } \\
\text { (min) }\end{array}$ & $\begin{array}{c}\text { Apgar } \\
\text { Score } \\
\text { 1 min }\end{array}$ & $\begin{array}{c}\text { Apgar } \\
\text { Score } \\
\mathbf{5} \text { mins }\end{array}$ \\
\hline & $\begin{array}{c}\text { Mean } \\
\text { (SD) }\end{array}$ & $\begin{array}{c}\text { Mean } \\
\text { (SD) }\end{array}$ & $\begin{array}{c}\text { Mean } \\
\text { (SD) }\end{array}$ & $\begin{array}{c}\text { Mean } \\
\text { (SD) }\end{array}$ & $\begin{array}{c}\text { Mean } \\
\text { (SD) }\end{array}$ & $\begin{array}{c}\text { Mean } \\
\text { (SD) }\end{array}$ \\
\hline Group & 198.3 & 2.2 & 21.2 & 219.6 & 6.8 & 8.8 \\
I & 29.1 & 0.3 & 13.6 & 37.9 & 0.7 & 0.7 \\
\hline Group & 252.1 & 1.68 & 22.74 & 274.84 & 6.64 & 8.58 \\
II & 23.05 & 0.155 & 12.11 & 29.09 & 0.72 & 0.75 \\
\hline Group & 382.78 & 1.11 & 30.94 & 413.72 & 6.22 & 8.08 \\
II & 42.38 & 0.108 & 13.6 & 47.75 & 0.89 & 0.944 \\
\hline \multicolumn{7}{|c|}{ Table I: Mean Labour Data } \\
\hline
\end{tabular}

\begin{tabular}{|c|l|l|l|l|l|l|}
\hline $\begin{array}{c}\text { Group } \\
\text { I vs II }\end{array}$ & 0.0003 & 0.0001 & 0.55 & 0.0005 & 0.03 & 0.117 \\
\hline $\begin{array}{c}\text { Group } \\
\text { I vs III }\end{array}$ & 0.0007 & 0.0004 & 0.005 & 0.0001 & 0.002 & 0.0036 \\
\hline $\begin{array}{c}\text { Group } \\
\text { II vs III }\end{array}$ & 0.0006 & 0.0001 & 0.0019 & 0.00005 & 0.0086 & 0.0041 \\
\hline \multicolumn{6}{|c|}{ Table II: Comparative Values of P Value } \\
\hline
\end{tabular}

Duration of active phase labour: There was significant reduction in active phase of labour in drotaverine hydrochloride (group I) as mean duration was 3 hours 18 minutes, whereas in valethamate bromide (group II) it was 4 hours 12 minutes. The value was statistically significant comparing with the control group (group III), in which the duration was 6 hours 23 minutes as shown in the table. The duration of labour was reduced by $50 \%$ (3 hours 18 minutes in group I vs 6 hours 23 minutes in group III) in drotaverine hydrochloride injection and $33 \%$ by valethamate bromide ( 4 hours 12 minutes in group II vs 6 hours 23 minutes in group III). Rate of cervical dilatation: The rate of cervical dilatation higher in drotaverine hydrochloride (Group I) $2.2 \mathrm{~cm} / \mathrm{hr}$. and valethamate bromide (Group II) $1.68 \mathrm{~cm} / \mathrm{hr}$. compared with control group (Group III) $1.11 \mathrm{~cm} / \mathrm{hr}$. Second stage of labour: There was significant shortening of the duration of second stage of labour in drotaverine hydrochloride group I and valethamate bromide group II when compared with the control group; 21.2 minutes in Group I vs 22.74 minutes in Group II vs 30.94 minutes in Group III. There was no difference between Group I and Group II $(\mathrm{p}<0.055)$. Injection delivery interval: Injection delivery interval was significantly shorter in drotaverine hydrochloride (Group I) 3 hours 40 minutes than valethamate bromide (Group II) 4 hours 35 minutes and control group 6 hours 54 minutes. APGAR score: First minute of Apgar score was better in drotaverine hydrochloride (Group I-6.8). Valethamate bromide (Group II-6.6) comparing control group (Group III-6.2). The 5 minute Apgar score showed no significant difference (8.8 in Group I, 8.58 Group II and 8.09 in Group III).

\begin{tabular}{|c|c|c|c|c|}
\hline \multirow{2}{*}{$\begin{array}{c}\text { VAS-Quality of } \\
\text { Pain Relief }\end{array}$} & \multicolumn{2}{|c|}{ Group I } & \multicolumn{2}{c|}{ Group II } \\
\cline { 2 - 5 } & Cases & $\%$ & Cases & $\%$ \\
\hline 0-2 Excellent & - & - & - & - \\
\hline 2-4 Good & - & - & - & - \\
\hline 4-6 Satisfactory & - & - & - & - \\
\hline 6-8 Slight & 18 & 36 & 6 & 12 \\
\hline 8-10 No Relief & 32 & 64 & 44 & 88 \\
\hline Table III: Quality of Pain Relief \\
\hline
\end{tabular}

\begin{tabular}{|c|c|c|c|c|c|c|c|}
\hline \multirow{2}{*}{ Group } & \multirow{2}{*}{$\begin{array}{c}\text { No. of } \\
\text { Patients }\end{array}$} & \multicolumn{2}{|c|}{$\begin{array}{c}\text { Normal } \\
\text { Delivery }\end{array}$} & $\begin{array}{c}\text { Forceps } \\
\text { Delivery }\end{array}$ & \multicolumn{2}{c|}{ LSCS } \\
\cline { 3 - 8 } & & No. & $\%$ & No. & $\%$ & No. & $\%$ \\
\hline $\begin{array}{c}\text { I Drotaverine } \\
\text { Hydrochloride }\end{array}$ & 50 & 47 & 94 & 3 & 6 & - & - \\
\hline II Valethamate & 50 & 45 & 90 & 5 & 10 & - & - \\
\hline III Control & 50 & 39 & 78 & 8 & 16 & 3 & 6 \\
\hline \multicolumn{7}{|c|}{ Table IV: Mode of Delivery in Different Group } \\
\hline
\end{tabular}

' $\mathrm{p}$ ' $=0.499$

All the patients in Group I and II delivered vaginally. There was no abdominal delivery like LSCS in the study group, whereas 3 patients in Group III delivered by LSCS because of arrest of dilatation in 2 cases and for foetal distress in one case. 


\begin{tabular}{|c|c|c|c|c|c|c|}
\hline \multirow{2}{*}{ Group } & \multicolumn{2}{|c|}{ Group I } & \multicolumn{2}{c|}{ Group II } & \multicolumn{2}{c|}{ Group III } \\
\cline { 2 - 7 } & No. & $\mathbf{\%}$ & No. & $\mathbf{\%}$ & No. & $\mathbf{\%}$ \\
\hline $\begin{array}{c}\text { Failure of } \\
\text { Secondary Powers }\end{array}$ & 2 & 4 & 4 & 8 & 6 & 12 \\
\hline Foetal Distress & 1 & 2 & 1 & 2 & 2 & 4 \\
\hline Total & $\mathbf{3}$ & $\mathbf{6}$ & $\mathbf{5}$ & $\mathbf{1 0}$ & $\mathbf{8}$ & $\mathbf{1 0}$ \\
\hline Table V: Indications for Assisted Delivery \\
\hline
\end{tabular}

In group 3 patients $(6 \%)$ had forceps delivery, of them 2 due to failure of secondary power and 1 for foetal distress. In Group II 5 patients (10\%) had forceps delivery, in that 4 required for failure of secondary power and 1 for foetal distress. In Group III 8 patients (16\%) required forceps delivery, among them 6 due to failure of secondary power and 2 for foetal distress. The incidence of operative vaginal delivery is less in Group I than Group II. In Group I, operative vaginal delivery is reduced as $1 / 3^{\text {rd }}$ when compared to Group II.

\begin{tabular}{|c|c|c|c|c|c|c|}
\hline \multirow{2}{*}{ Side Effects } & \multicolumn{2}{|c|}{ Group I } & \multicolumn{2}{c|}{ Group II } & \multicolumn{2}{c|}{ Group III } \\
\cline { 2 - 7 } & No. & $\mathbf{\%}$ & No. & $\mathbf{\%}$ & No. & $\mathbf{\%}$ \\
\hline Headache & - & - & 3 & 6 & 2 & 4 \\
\hline Dryness of Mouth & 3 & 6 & 10 & 20 & - & - \\
\hline Tachycardia & 3 & 6 & 11 & 22 & 3 & 6 \\
\hline Flushing of Face & 0 & 0 & 3 & 6 & 0 & 0 \\
\hline Giddiness & 0 & 0 & 0 & 0 & 2 & 4 \\
\hline Sedation & 0 & 0 & 0 & 0 & 0 & 0 \\
\hline FHR Alterations & 0 & 0 & 1 & 2 & 1 & 2 \\
\hline Total Table VI: Side Effect of Drugs \\
\hline & 6 & $\mathbf{1 2}$ & $\mathbf{2 8}$ & $\mathbf{5 6}$ & $\mathbf{8}$ & $\mathbf{1 6}$ \\
\hline
\end{tabular}

On analysis minimal side effects were found in Group I $(6 \%)$ and major effects like foetal heart alterations, giddiness and headache were nil, whereas Group II showed 3 times increase in minimal side effects $(20 \%)$ and $2 \%$ major side effects like foetal heart alterations. Though the minimal effects $(6 \%)$ were in control, major side effects like headache and foetal heart alterations were same as Group II. Tachycardia was found to be minimal in Group I (6\%), whereas 4 times increased (22\%) in Group II.

\begin{tabular}{|c|c|c|c|c|c|c|c|}
\hline Group & No. of Cases & \multicolumn{5}{|c|}{ No. of Injection } \\
\hline & & 1 & 2 & 3 & 4 & 5 & Total \\
\hline I & 50 & - & 48 & 2 & - & - & 50 \\
\hline I & 50 & - & - & 20 & 29 & 1 & 50 \\
\hline \multicolumn{6}{|c|}{ Table VII: Comparison of Number of } \\
Injections Given in Different Groups \\
\hline
\end{tabular}

Group I - 48 (96\%) patients required 2 injections and only 2 (4\%) patients required 3 injections. Group II - 20 (40\%) patients required 3 injections and $29(58 \%)$ patients required 4 injections and only one (2\%) patient required 5 injections. So more number of injections required in Group II compared with Group I.

\section{DISCUSSION}

The labour is defined as the uterine contractions that bring about demonstrable effacement and dilatation of cervix Dystocia literally means difficult labour and is characterized by abnormally slow progress of labour. Labour is a multifactorial process, which involves myometrial contraction, cervical ripening and dilatation and the expulsion of the foetus and placenta in an orderly manner. The first stage of labour in a primigravida lasts about 12-16 hrs. and in a parous woman 6-8 hrs. Abnormalities of labour include prolonged latent phase, prolonged active phase, secondary arrest of dilatation, prolonged deceleration phase, failure of descent, protracted descent, arrest of descent and precipitate labour. Prolonged labour has been a dreaded problem for obstetricians. The most common cause of prolonged first stage of labour is cervical spasm leading to cervical dystocia. Causes of cervical dystocia include rigidity of cervix like hypertrophic rigidity and cicatricial rigidity, atresia of cervix, sacculation of cervix. Various treatment modalities studied to overcome cervical dystocia include vacuum, cervical vibrators, cervical incision and caesarean section. Full cervical dilatation is one of the important factors for any successful vaginal delivery. Cervical spasm may set in either gradually or instantly during the first stage of labour irrespective of the age, parity and may be primary without any explainable aetiology or may be secondary to some definite aetiology or aetiopathology. The relaxation of cervical muscle is believed to be an involuntary reflex action coupled with rhythmic contraction of the body of the uterus. More powerful the contraction of the uterus, the better the relaxation of the cervical smooth muscles. It is also believed that relaxation is dependent on the presenting part and the bag of membranes, which act as a mechanical wedge and brings about cervical dilatation. A "ball valve action" of the presenting part, especially the vertex is also helpful in dilatation. Cervical spasm may continue or increase in presence of inflammation, injuries, fibrosis or disparity in the nervous mechanism such as loss of polarity and incoordinate uterine contractions. Prolonged labour is a problem, especially prolonged first stage where incomplete cervical dilatation appears to be the only cause holding back the descent of the presenting part. Spasmolytic drugs help to relieve cervical spasm and facilitate cervical dilatation during the first stage of labour. Drotaverine is a newer spasmolytic drug, which is claimed to reduce the duration of labour by accelerating cervical dilatation without causing side effects. It is claimed to be safe with no side effects and no drug interactions. It inhibits phosphodiesterase enzyme which breaks cyclic AMP and cyclic GMP, which play an important role in regulation of smooth muscle tone. Many authors have reported the usefulness of drotaverine hydrochloride in accelerating the dilatation of cervix and observed that the duration of labour was shortened by $18-30 \%$. Normalization of irregular uterine contractions improved the process of cervical dilatation. Epidosin (Valethamate bromide) is also an antispasmodic, which helps in cervical dilation due to its neurotropic or atropine like action and musculotropic or papaverine-like action. Drotaverine hydrochloride is a musculotropic, antispasmodic drug acting directly on smooth muscle cells. It acts by- 1 direct musculotropic action; its action does not involve the autonomic nervous system and so side effects are less. The use of drotaverine hydrochloride during pregnancy has not shown any detectable teratogenic effects in the study. Valethamate bromide is an ester with a quaternary $\mathrm{N}$-atom having spasmolytic action by virtue of its anti-cholinergic action and musculotropic action. Valethamate bromide exerts a preferential parasympatholytic or an anti-cholinergic effect on smooth muscles of gastrointestinal tract and genitourinary tract. Apart from the anti-muscarinic effect, valethamate 
bromide exerts very little effect on the circulation, exocrine secretions. Valethamate bromide does not exert serious CNS side effects. Its onset of action is rapid and the duration of effect is not unduly prolonged. This was the study comparing the efficacy of the two drugs drotaverine hydrochloride and valethamate bromide on cervical dilatation and its effect on partogram. Study of 150 primigravidae with labour pains divided into three groups of 50 patients each. In group I, patients were given injection drotaverine hydrochloride 40 mg IM and repeated every 2 hours for a maximum of 3 injections. In Group II, patients were given injection of valethamate bromide $8 \mathrm{mg}$ intravenous every hour for five doses. In Group III, patients were not given any drugs and acted as controls. Drotaverine hydrochloride (Group 1) significantly reduced the duration of active phase of labour (3 hrs. $18 \mathrm{~min}$ ) than valethamate bromide (Group II) ( $4 \mathrm{hrs} . / 12$ mins) and control Group III (6 hrs./23 mins). This study correlated with previous study by Kaur Devinder, Kaur Ravinder et al and S. L. Mishra et al.[1] Rate of cervical dilatation was increased in drotaverine hydrochloride (Group I), which was $2.2 \mathrm{~cm} / \mathrm{hr}$. than in valethamate bromide (Group II), which was $1.68 \mathrm{~cm} / \mathrm{hr}$.) compared with control Group III, which was $1.11 \mathrm{~cm} / \mathrm{hr}$. Duration of second stage of labour reduced significantly with drotaverine hydrochloride (Group I) (21.2 mins) and valethamate bromide (Group II) (22.74 mins) than control group (Group III 30.94 mins). This study was comparable with the study of Demeter and Blasko et al.[2] Drotaverine hydrochloride (Group I) and valethamate bromide (Group II) showed no difference in the duration of second stage. Injection delivery interval was shorter with drotaverine hydrochloride (Group I) (3 hrs., 40 mins) than valethamate bromide (Group II) (4 hrs., 35 mins) and control group (Group III) (6 hrs., 54 mins).

First minute Apgar score was better in drotaverine hydrochloride (Group I (6.8) and valethamate bromide (Group II) (6.6)) compared to control group (Group III) (6.2). Five minute Apgar score showed no significant difference in Group I (8.8). Group II (8.58) and Group III (8.08). This study is comparable with study of Dr. Poornima R et al.[3] There was only slight pain relief in the study group (Group I and Group II), but among the two groups Group I was three times more potent (36\%) than Group II (12\%). This study correlated with study of Farkas M, Viski S et al.[4] Drotaverine hydrochloride (Group I) reduced the duration of first stage of labour, gives pain relief and thereby reduces maternal exhaustion so that maternal expulsive forces are left intact with maximum powers. This allows a spontaneous normal vaginal delivery. Therefore, operative vaginal delivery is less with drotaverine hydrochloride (Group I) compared to valethamate bromide (Group II) and Control group III. Analysing the effect of drug and foetal outcome, foetal distress was four times more common in Group III (Control) than group I and group II. On comparison, drotaverine hydrochloride is $50 \%$ more safe and had reduction in foetal distress than valethamate bromide $(2 \%$ vs $4 \%$ ). On analysing the side effects in Group I minor side effects like dryness of mouth, tachycardia were found in $6 \%$ and major effects like foetal heart alterations, giddiness and headache were nil. In Group II, there was three times increase in minimal side effects (20\%) and $2 \%$ major side effects like foetal heart alterations. Tachycardia was found to be minimal in Group I (6\%), whereas four times increased in Group II (22\%). This study is comparable to that reported by Markley L, Tury P and Goswami et al.[5]

\section{CONCLUSION}

Drotaverine hydrochloride (Group I) is a safe, potent effective drug to be used in the active management of labour. It shortens the duration of labour by $50 \%$ and augments the rate of cervical dilation $(2.2 \mathrm{~cm} / \mathrm{hr}$.) without any untoward maternal or foetal side effects. The drug drotaverine hydrochloride (Group I) is 2 times more potent and superior to valethamate bromide (Group II) in achieving effective cervical dilation and shortening the first stage of labour. Major side effects like foetal heart alterations is nil with drotaverine. The drug drotaverine hydrochloride gives better pain relief in labour patients when compared with valethamate bromide. The study proves the superiority of drotaverine hydrochloride over valethamate bromide in both cost and management of labour. To conclude the safety, efficacy, cost effectiveness along with labour analgesia is superior with drotaverine hydrochloride than valethamate bromide.

\section{REFERENCES}

1. Devinder K, Ravinder K. Comparison of drotaverine and episodin in first stage of labour. Journal of Obstetrics \& Gynaecology, India 2003;53(5):449-53.

2. Farkas M, Viski S. Relief of pain in childbirth by a new antispasmodic. Ther hung 1967;15(4):153-4.

3. Poornima R, Ranka A, Hishikar. Effect of drotaverine hydrochloride on normal labour-a randomized study. Journal of Obstetrics \& Gynaecology India 2002;52(6): 28-30.

4. Goswami B, Sarkar M, Biswas B. Efficacy of drotaverine and valethamate bromide in active management of labour. Abstract book, XVI FIGO World Congress of Gynaecology and Obstetrics, Washington DC, USA, 2000.

5. Blasko ST, Demeter J. The effect of intramuscularly administered drotaverine on the dilatation stage of uncomplicated delivery. Obstet Gynaecol Today 1998;3(12):723-37. 